\title{
LOKALITAS SEBAGAI IDENTITAS MASYARAKAT KAMPUNG MAHMUD
}

\author{
Anggar Erdhina Adi \\ Fakultas Industri Kreatif \\ Telkom University Bandung Indonesia \\ JI. Telekomunikasi No. 1, Bandung Technoplex, Terusan Buah Batu, Bandung \\ Email:anggarwarok@telkomuniversity.ac.id
}

\begin{abstract}
ABSTRAK
Artikel ini merupakan hasil penelitian tentang lokalitas sebagai identitas masyarakat kampung Mahmud. Sebagai salah satu kampung yang memiliki keunikan adat dan tradisi, kampung Mahmud kini menghadapi berbagai macam tantangan baik dari masyarakat dalam maupun luar. Imbasnya adalah muncul berbagai macam persoalan baik secara sosial maupun kultural. Hal ini dikarenakan lemahnya pewarisan identitas tentang lokalitas masyarakat Kampung Mahmud. Penelitian ini memiliki tujuan agar menjadi pemahaman mengenai lokalitas sebagai identitas kultural, khususnya untuk masyarakat kampung adat. Sebagai sebuah kampung religi yang harus memiliki identitas kelokalan, kampung Mahmud seringkali berbenturan dengan nilai adat dan tradisi yang datang dari luar dan kian mengaburkan identitas kultural kampung tersebut. Metode yang digunakan dalam penelitian ini adalah kualitatif dengan menggunakan pendekatan etnografi. Sedangkan tipe penelitiannya adalah penelitian deskriptif kualitatif. Hasil yang didapatkan adalah perlu adanya penguatan nilai lokalitas sebagai identitas kultural masyarakat Kampung Mahmud.
\end{abstract}

Kata kunci: Lokalitas, Identitas, Kampung Mahmud.

\section{ABSTRACT}

This article is the result of research on locality as the identity of the Mahmud village community. As one of the villages that has unique customs and traditions, Mahmud village is now facing a variety of challenges both from inside and outside the community. The impact is that various problems arise both socially and culturally. This is due to the weak inheritance of identity about the locality of Kampung Mahmud people. This study aims to find an understanding of locality as a cultural identity, especially for traditional village communities. As a religious village that must have a local identity, Kampung Mahmud often clashes with traditional values and traditions that come from outside and it increasingly obscures the village's cultural identity. The method used in this study is qualitative using an ethnographic approach. The research is a qualitative descriptive study. The results obtained show the need to strengthen the value of locality as a cultural identity of Kampung Mahmud.

Keywords: Locality, Identity, Kampung Mahmud.

\section{A. Pengantar}

Sebagai salah satu kampung yang memiliki keunikan adat dan tradisi, kampung Mahmud kini menghadapi berbagai macam tantangan baik dari dalam maupun luar. Tantangan ini menjadi lebih berat karena perkembangan jaman sudah menjadi bagian yang tidak bisa dipisahkan dari kampung tersebut. Posisinya sebagai tempat ziarah bagi banyak orang menjadikan kampung ini menjadi ramai dikunjungi. Imbasnya adalah muncul berbagai macam persoalan baik secara sosial maupun kultural. Selain itu generasi muda di kampung tersebut juga sudah mulai banyak meninggalkan nilai-nilai dan ajaran yang diwariskan secara turun temurun. Pewarisan ini seharusnya menjadi sebuah nilai yang dapat menjaga identitas masyarakat Kampung Mahmud.

Kampung Mahmud merupakan salah satu kampung adat yang terletak pinggiran kota Bandung, lebih tepatnya di Desa Mekarrahayu Kecamatan Marga Asih Kabupaten Bandung Selatan. Menurut KH Muhammad Syafei-sesepuh Kampung Mahmud dan juga keturunan ke 9 Eyang Dalem Abdul Manaf-, kampung ini dibangun oleh Eyang Abdul Manaf yang dianggap sebagai turunan wali dari Cirebon. Kampung ini menurut beberapa sumber dibangun pada abad ke 15 Masehi sekitar tahun $1405 \mathrm{M}$.

Menurut KH Muhammad Syafei, Eyang Abdul Manaf pergi ke Mekah meninggalkan kampung halamannya dan tinggal di sana untuk waktu yang 


\section{GE $[A R$ Jurnal Seni Budaya}

cukup lama. Setelah mendapatkan ilmu agama yang cukup, Eyang Abdul Manaf kemudian pulang dengan membawa sekepal tanah dari Mekah. Setelah berkeliling, akhirnya Eyang Abdul Manaf menemukan sebuah tanah rawa seperti pulau yang dibelah oleh sungai. Tanah rawa inilah yang kemudian menjadi cikal bakal Kampung Mahmud dan menjadi tempat berdakwah dan menyepi.

Menurut Muhammad Syafei, kampung Mahmud adalah cikal bakal dari penyebaran agama Islam khususnya di Bandung, sehingga banyak orang yang datang untuk berziarah ke makam Eyang Dalem Abdul Manaf. Sebagai tempat wisata religi, kampung Mahmud banyak dikunjungi wisatawan baik untuk berziarah, wisata religi ataupun hanya sekedar berkunjung.

Namun terkadang memang ada beberapa orang dari luar yang akhirnya menetap disana ataupun menikah dengan perempuan di Kampung Mahmud. Dengan beragamnya pendatang yang memasuki kampung Mahmud, baik menetap atau tidak, kondisi ini kemudian menjadi salah satu penyebab lunturnya identitas kelokalan yang dimiliki oleh Kampung Mahmud.

Selain itu gencarnya teknologi dan informasi yang masuk dalam generasi muda melalui internet, semakin membuat regenerasi estafet nilai adat dan tradisi menjadi semakin menipis. Hal ini diperparah dengan munculnya beberapa generasi muda yang mulai enggan dengan pelestarian identitas kelokalan yang dimiliki Kampung Mahmud. Tantangan terbesar adalah ada pada generasi muda, karena masih sangat rentan dengan nilai-nilai gaya hidup yang dianut dari media informasi yang didapatkan dari internet.

Keadaan ini dikhawatirkan akan membuat kampung Mahmud sebagai kampung religi-kadang disebut kampung Adat- yang memiliki ciri nilai adat dan tradisi yang diajarkan para leluhurnya akan semakin hilang. Dengan hilangnya identitas kelokalan tersebut, maka eksistensi kampung Mahmud sebagai kampung Religi semakin lama akan menghilang dan akan menjadi sebuah kampung yang sama dengan kampung-kampung biasa. Sebagai sebuah kampung yang seharusnya memiliki identitas kelokalan, kampung ini seringkali berbenturan dengan nilai adat dan tradisi yang datang dari luar. Keadaan ini kian mengaburkan identitas asli kampung tersebut. Dengan begitu maka sudah seharusnya kampung Mahmud harus siap mengantisipasinya. Artikel ini membahas mengenai lokalitas yang seharusnya menjadi identitas Kampung Mahmud.

\section{B. Metode Penelitian}

Metode yang digunakan dalam penelitian ini adalah metode penelitian dengan menggunakan pendekatan etnografi, sedangkan tipe penelitiannya adalah penelitian deskriptif kualitatif. Mengutip Bogdan dan Taylor dalam Ratna (2010:94), kualitatif adalah metode yang pada gilirannya menghasilkan data deskriptif dalam bentuk kata-kata, baik lisan maupun tertulis. Penelitian ini lebih menekankan pada hasil deskriptif. Metode ini sangat sesuai digunakan khususnya dalam fenomena budaya yang sangat sulit untuk mengkuantifikasinya. Model ini berupaya mempelajari berbagai macam peristiwa kultural yang terjadi di masyarakat Kampung Mahmud, dimana akan lebih banyak terkait pandangan hidup subyek sebagai objek yang akan diteliti (Endraswara, 2006; 50).

Adapun pengumpulan data yang digunakan penulis adalah dengan melakukan observasi partisipan, artinya keterlibatan penulis dalam penelitian di lapangan akan menjadi sangat penting. Penelitian ini dilakukan dari tahun 2019 hingga 2020 di Kampung Mahmud, Kabupaten Bandung dengan mengedepankan observasi partisipan. Observasi partisipan atau dalam ilmu etnografi adalah kerja lapangan (fieldwork) menjadi salah satu hal yang paling penting. Penelitian lapangan yang dilakukan tidak hanya satu kali, namun dilakukan dengan waktu cukup lama.

\section{Pembahasan}

Sebagai kampung religi, kampung Mahmud menetapkan tata nilai dan aturan adat dalam kehidupan sehari-hari. Aturan ini menjadi salah satu tonggak untuk menjaga kelestarian dari kampung tersebut. Aturan yang diterapkan di kampung ini adalah hukum yang tidak tertulis untuk mengatur kehidupan sosial masyarakat Kampung Mahmud, namun diyakini oleh masyarakat disana.

Tidak bisa dipungkiri bahwa kemajuan jaman adalah salah satu tantangan terbesar. Niat awal Eyang Dalem Abdul Manaf untuk menjadikan tempat tersebut sebagai tempat untuk menepi dari keramaian tidak bisa ditolak lagi. Semenjak pembangunan jembatan yang menghubungkan dengan desa sebelah, kampung ini menjadi ramai dikunjungi. Takhanya untuk mengaji namun juga untuk berziarah dan kepentingan lainnya. Ditambah dengan arus informasi dari luar yang masuk melalui internet dan smartphone. Menjadikan kampung ini menghadapi tantangan yang semakin 
berat untuk mempertahankan diri sebagai kampung religi.

\section{Gempuran Identitas Kultural di Kampung Mahmud}

Sebagai sebuah kampung Religi, kampung Mahmud mempunyai ciri khas. Salah satu yang melekat adalah sebagai tempat wisata religi dan sejarahnya. Ciri ini merupakan salah satu diantara sekian banyak unsur yang melekat dalam masyarakat tersebut sebagai sebuah identitas. Seperti yang diungkapkan Jakob Soemardjo $(59 ; 2014)$ identitas adalah keselarasan diantara unsur-unsur yang berbeda dan didukung oleh kesimetrisan dan keseimbangan yang terjadi diantara kelompok masyarakat. Unsurunsur yang berbeda ini muncul ketika Eyang Dalem Abdul Manaf mulai kedatangan murid-murid dari berbagai wilayah dari Bandung. Namun keragaman yang muncul disana lambat laun menjadi sebuah keselarasan dan keserasian. Meskipun memiliki keragaman namun identitas mereka menyatu dengan aturan maupun petunjuk dari Eyang Dalem. Dimana kondisi ini membuat sebuah hubungan abstrak yang kemudian menyatu menjadi sebuah identitas sebagai kampung Mahmud.

Narasi tentang kisah terbentuknya kampung Mahmud diturunkan secara terus menerus, baik dari kalangan keturunan maupun para peziarah dan ulama yang kemudian menyebar ke berbagai daerah. Narasi tersebut sebagaimana dijelaskan oleh Parker (2005) adalah bagian dari penampakan diri dari sebuah identitas.

Namun ketika kampung ini sudah memiliki keselarasan dalam masyarakat -masyarakat kampung Mahmud yang dulu-, muncul berbagai macam tantangan secara sosio dan kultural. Salah satunya adalah kemajuan jaman. Meskipun identitas kultural sebenarnya lebih merupakan konstruksi sosial budaya dari masyarakat dan/atau bangsa tertentu yang terbentuk oleh gabungan dari berbagai faktor, namun harusnya perlu diberikan rambu-rambu untuk menjaganya (Pawito 2010: 9). Faktor-faktor yang mempengaruhi memang sangat banyak diantaranya faktor sejarah, faktor budaya, faktor etnis, faktor bahasa, faktor agama dan faktor kondisi-kondisi wilayah geografis.

Salah satu fokus utama dalam artikel ini adalah kehidupan sosial yang berubah, sehingga menjadikan kampung ini menghadapi gempuran identitas dari berbagai macam bentuk. Keinginan Eyang Dalem untuk menjadikan kampung ini sebagai tempat menyepi (sufi) menjadi sulit dihindarkan.
Keinginan masyarakat luar untuk memiliki tanah kuburan di dekat Maqom Mahmud juga menjadi tantangan baik dalam dimensi sosio maupun kultural. Harga tanah kuburan yang mahal ini ternyata menurut Rustandi (56 tahun) ketua RW yang dulu, menjadikan cara berfikir pemilik tanahnya berubah. Persoalan sosial dan kultural ini merambat dalam berbagai lini kehidupan, misalkan tentang mata pencaharian. Tuntutan kehidupan jaman yang semakin berkembang menjadikan masyarakat disana berkembang. Ada yang masih bertahan dan ada juga yang kemudian melanjutkan kehidupan perekonomian di luar kampung.

Tuntutan jaman mau tidak mau akan mempengaruhi identitas kultural masyarakat disana. Padahal jika digali lebih jauh, banyak sekali ajaran yang ditinggalkan yang dijadikan nilai adat dan tradisi kampung Mahmud yang menjadi identitas kultural.

\section{Nilai Adat dan Tradisi Kampung Mahmud}

Beragam nilai adat dan tradisi yang diturunkan oleh leluhur Kampung Mahmud yang tentu mengandung nilai dan makna. Diantaranya adalah :

\subsection{Makam Eyang Mahmud}

Kampung Mahmud pada awalnya adalah sebuah rawa. Eyang Dalem Mahmud yang membawa sekepal tanah dari Mekkah kemudian menaburkannya di rawa tersebut. Tempat menaburkan tanah tersebut kini menjadi Masjid Agung yang menjadi tempat penyiaran agama islam di Bandung. Setelah meninggal Eyang Dalem Mahmud dimakamkan di dalam Kampung Mahmud yang kini dijadikan sebagai tempat ziarah. Banyak penziarah yang datang, baik dari dalam kota maupun luar kota untuk berziarah di makam Eyang Mahmud.

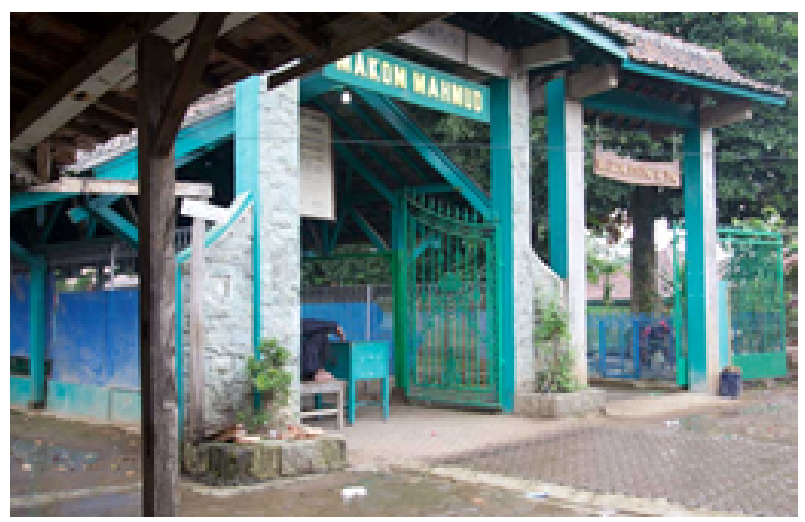

Gambar 1. Makom Mahmud yang terletak di sebelah barat Masjid Agung.

(Foto: Anggar Erdhina A, 2019) 


\section{GE[AR sumal Sori Bublya}

Berziarah ke makam sebenarnya diturunkan sebagai salah satu wadah untuk lebih mendekatkan diri kepada Allah SWT dengan mengingat kematian. Namun jika melihat perkembangannya memang terdapat beberapa hal yang kadang tidak sesuai dengan ajaran yang sudah diajarkan oleh Eyang Dalem.

\subsection{Rumah Panggung}

Rumah panggung merupakan rumah adat Kampung Mahmud yang menjadi ciri khas disana. Rumah ini memiliki ciri panggung dan menggunakan bahan kayu serta dinding memakai bilik bambu. Nilai adat yang diajarkan dari bangunan ini adalah cerminan kesederhanaan dan rendah hati. Selain itu nilai yang lain adalah, karena yang akan dibawa ke akhirat bukan kemegahan, melainkan iman dan taqwa kepada Allah SWT.
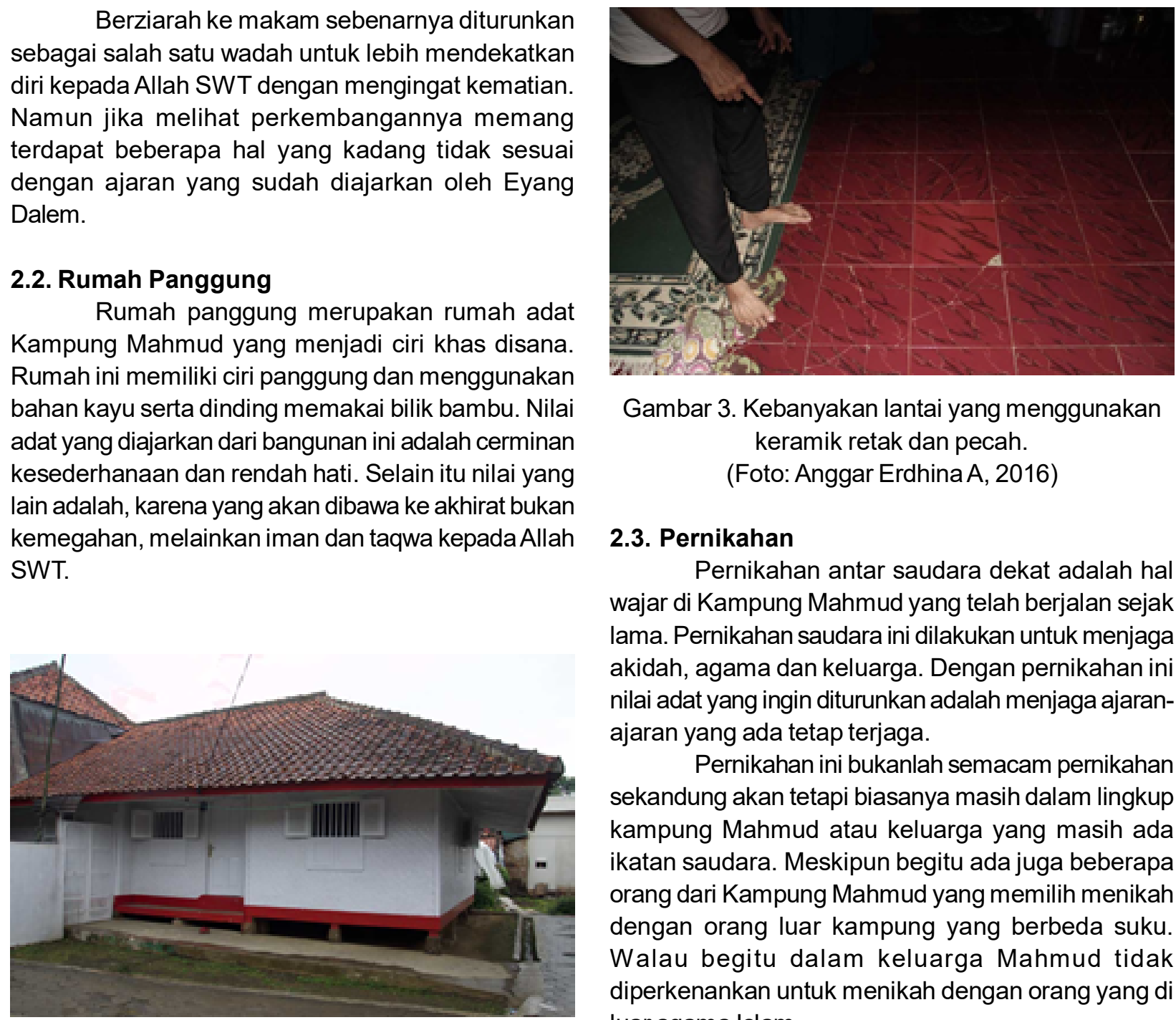

Gambar 3. Kebanyakan lantai yang menggunakan keramik retak dan pecah.

(Foto: Anggar Erdhina A, 2016)

\subsection{Pernikahan}

Pernikahan antar saudara dekat adalah hal wajar di Kampung Mahmud yang telah berjalan sejak lama. Pernikahan saudara ini dilakukan untuk menjaga akidah, agama dan keluarga. Dengan pernikahan ini nilai adat yang ingin diturunkan adalah menjaga ajaranajaran yang ada tetap terjaga.

Pernikahan ini bukanlah semacam pernikahan sekandung akan tetapi biasanya masih dalam lingkup kampung Mahmud atau keluarga yang masih ada ikatan saudara. Meskipun begitu ada juga beberapa orang dari Kampung Mahmud yang memilih menikah dengan orang luar kampung yang berbeda suku. Walau begitu dalam keluarga Mahmud tidak diperkenankan untuk menikah dengan orang yang di luar agama Islam.

Gambar 2. Rumah Panggung di kampung Mahmud. (Foto: Anggar Erdhina A, 2019)

Nilai adat yang diturunkan tersebut muncul dalam sebuah aturan tidak tertulis yang melarang rumah Mahmud menggunakan semen. Bagi siapa yang menggunakan semen, maka rumah tersebut tidak akan bertahan lama (misalkan mudah retak dan pecah). Hal tersebut masih dipercaya, namun tidak sedikit masyarakat Mahmud tetap menggunakan semen sebagai salah satu bahan bangunan rumah mereka. Meski demikian, material kayu tetap dominan sebagai bentuk arsitektural rumah di Kampung Mahmud yang identik dengan nuansa tradisional Sunda.

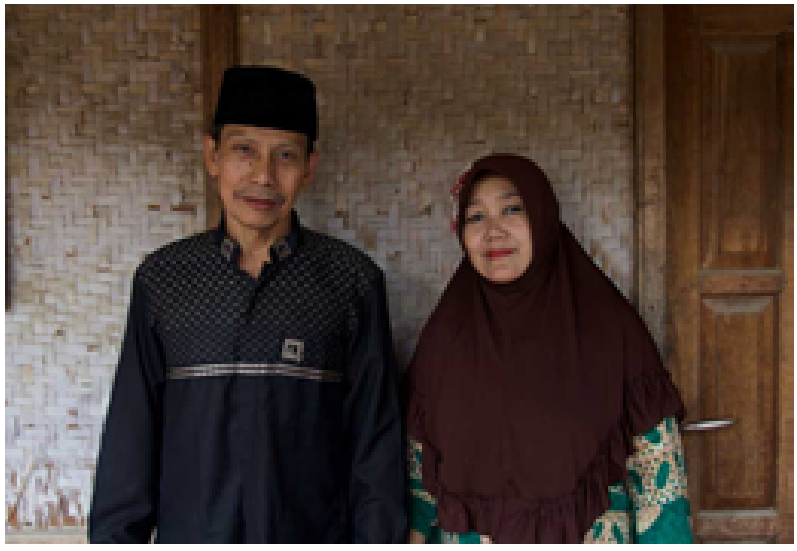

Gambar 4. Haji Nuron dan Istrinya yang juga masih kerabat. (Foto: Anggar Erdhina A, 2016) 
Salah satu contohnya adalah Haji Nuron. Sebagai salah satu keturunan dari Eyang Dalem Abdul Manaf, beliau menikah dengan seorang perempuan yang masih memiliki garis keturunan di Kampung Mahmud. Hal ini dikarenakan menurut Haji Nuron kedekatan kultural menjadikan perjalanan ke depannya akan lebih mudah.

\subsection{Pendidikan}

Pendidikan di Kampung Mahmud masih mengandalkan pendidikan pesantren, entah di luar Kampung Mahmud atau mengaji di Kyai-kyai yang ada di lingkungan Kampung Mahmud. Namun selain pendidikan keagamaan, di Kampung Mahmud juga sudah dibangun sekolah formal, yaitu Madrasah. Sekolah ini dibangun oleh PakAdam berbekal sekolah formal di luar kampung Mahmud.

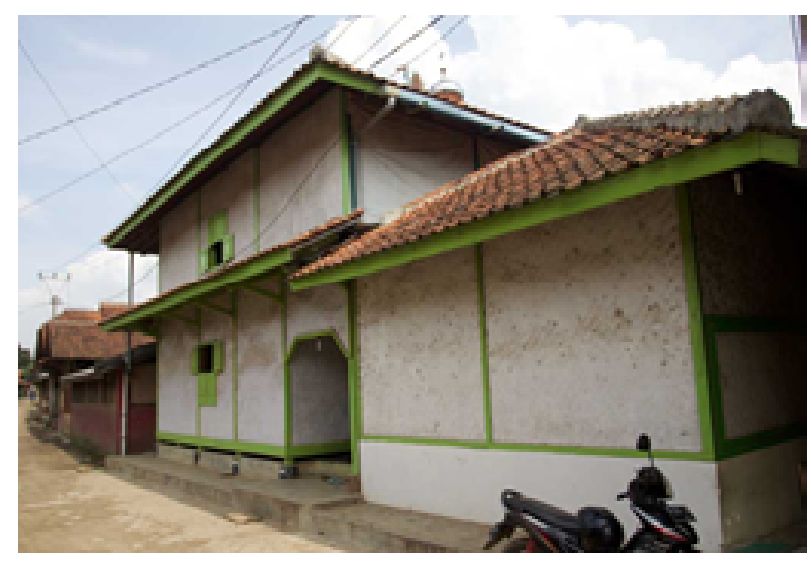

\section{Gambar 5. Mushola yang juga sekaligus tempat mengaji. \\ (Foto: Anggar Erdhina A, 2016)}

Masyarakat Kampung Mahmud umumnya masih mengandalkan pendidikan non formal yaitu mengaji di pesantren-pesantren kecil yang dikelola oleh kyai-kyai atau sepuh yang ada disana. Setiap sore maupun malam kegiatan mengaji di tempattempat tersebut dipenuhi anak-anak kecil yang belajar mengaji. Meskipun tidak semua, namun sebagian besar anak-anak disana menjadikan aktifitas mengaji adalah rutinitas harian yang tidak bisa ditinggalkan.

\subsection{Terbangan}

Pada tahun baru Islam masyarakat Kampung Mahmud biasanya meramaikan hari tersebut. Pada acara tersebut, banyak remaja yang ikut hadir. Remaja di sana sangat antusias mengikuti acara, mulai dari ceramah, pembacaan doa, melihat pentas musik terbangan, hingga saweran. Sesi saweran dibagi menjadi beberapa sesi, yaitu sesi remaja laki-laki, anak laki-laki, anak perempuan, hingga ibu-ibu. Saat sesi saweran remaja laki-laki, para remaja tersebut saling merebut uang saweran.

Remaja laki-laki di Kampung Mahmud umumnya banyak terlibat dalam kegiatan musik, yaitu Terbangan. Terbangan adalah kesenian musik yang menggunakan semacam rebana yang dimainkan oleh beberapa orang. Kesenian terbangan di kampung Mahmud hanya boleh dimainkan oleh laki-laki. Biasanya kesenian ini dimainkan pada acara-acara besar yang diadakan di Kampung Mahmud.

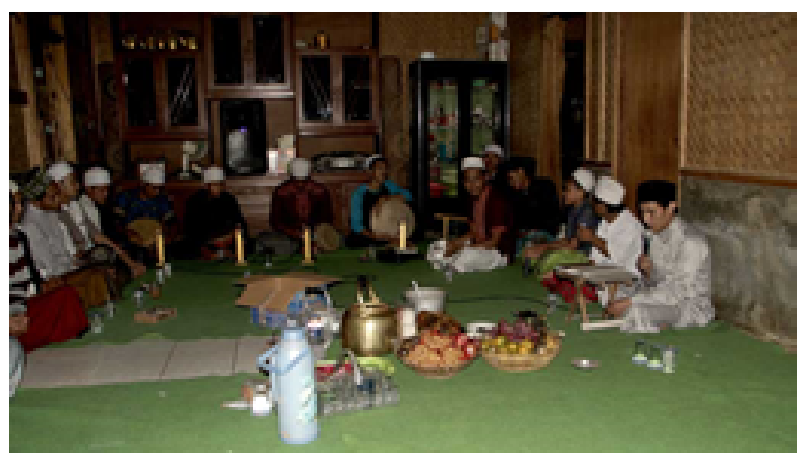

Gambar 6. Acara terbangan di Rumah Haji Nuron. (Foto: Anggar Erdhina A, 2016)

\subsection{Larangan}

Masyarakat Kampung Mahmud juga memiliki larangan-larangan yang telah diturunkan oleh leluhur. Konon bila melanggar larangan tersebut maka akan mendapat musibah. Pantangan atau larangan di kampung Mahmud, yaitu: Memukul gong dan bedug, menggunakan semen untuk membangun rumah, memakai kaca untuk jendela rumah, dangdut dan memelihara soang -sejenis angsa dengan suara nyaring-.

Alasan untuk tidak memperbolehkan memukul Gong atau Bedug karena suara dari kedua benda tersebut dapat menjadi perhatian penjajah pada masa itu -Kolonialisme Belanda-. Kampung Mahmud sengaja berada di tempat yang tersembunyi supaya dapat menjadi tempat syiar agama yang tenang dan jauh dari gangguan penjajah. Begitu juga dengan memelihara Soang yang menimbulkan suara yang nyaring.

\section{Lokalitas Kampung Mahmud}

Lokalitas sebenarnya sudah menyatu dalam kehidupan sehari-hari masyarakat kampung 


\section{GEEAR Jumal sai isulya}

Mahmud, sehingga identitas ini bukanlah sesuatu yang susah untuk dipahami. Cerminan dari lokalitas terselip dan banyak sekali muncul dalam petuah dan ajaran yang diturunkan dari sesepuh. Beberapa ditunjukkan secara langsung namun yang lainny tidak.

Dari hasil pengamatan di lapangan, ditemukan bahwa beberapa hal yang sudah ditetapkan oleh sesepuh memang benar adanya. Misalkan ketika membangun rumah menggunakan semen. Masalah yang muncul bukanlah serta merta hancurnya bangunan (lantai retak), akan tetapi lebih kepada retaknya nilai-nilai kebersamaan dan kesetaraan. Karena perbedaan menjadi semakin jelas dan semakin lama menjadi sebuah hubungan sosial yang terbelah (retak/belah). Larangan tersebut sebenarnya memiliki nilai yang sangat dekat dengan masyarakat setempat, namun masih banyak yang melanggar.

Nilai lokalitas ini sebenarnya menyatu dalam pemahaman kultural, namun karena tidak dipahami maka semua hanya dianggap mitos belaka. Cerita yang turun temurun tersebut menjadi mitos tradisional. Mitos ini merupakan sebuah kristalisasi pemahaman yang ada karena cara paling mudah untuk memahami sebuah ajaran adalah dengan cerita. Dalam rentang waktu tertentu cerita ini akan membentuk pola dan tatanan masyarakat (Pilliang \&Jaelani, 2018; 108). Dengan begitu masyarakat akan memahaminya sebagai sebuah keselarasan dalam hidup bermasyarakatnya.

Pada umumnya masyarakat tradisional memiliki cerita mereka sendiri karena inti dari mitos masyarakat tradisional adalah cerita. Dalam setiap unsur cerita tersebut tidak dapat dihindarkan pastinya memiliki nilai lokalitas. Lokalitas memang tidak hanya bermakna tentang cakupan daerah (lokal), akan tetapi mengenai nilai-nilai yang menyatu dalam kehidupan sehari-hari dan sangat bernilai lokal.

Jika diuraikan dalam skema sederhana, maka mitos tradisonal tersebut dapat menjadi identitas masyarakat Kampung Mahmud. Mitos tradisional yang hidup dari dulu hingga sekarang seharusnya dikembalikan seperti pada zaman dahulu. Dengan begitu nilai-nilai lokalitas akan tetap hidup dan menjaga identitas masyarakat Kampung Mahmud. Hal ini bisa dilihat dari skema di bawah ini :
Pantangan, Larangan dan Petuah

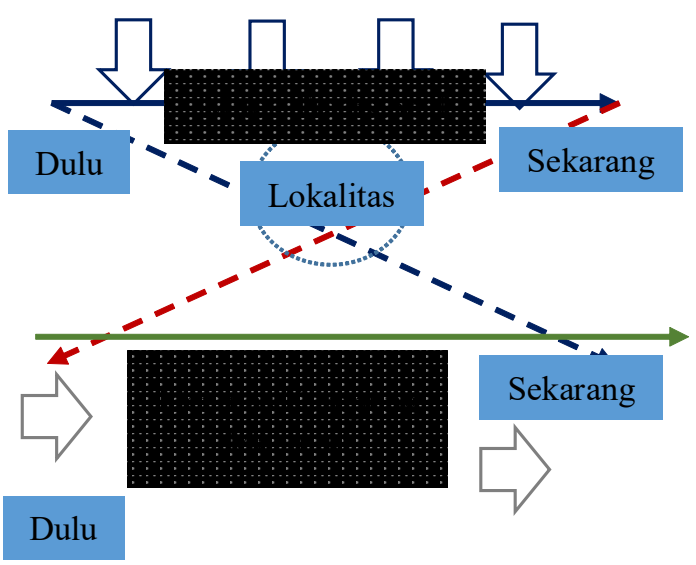

Gambar 7. Lokalitas di Kampung Mahmud yang seharusnya menjadi Identitas.

Pantangan, larangan maupun aturan yang sudah ada di Kampung Mahmud jika dilihat fungsinya dari yang dulu dan sekarang tentu akan terus bergerak dan berubah. Namun jika kondisi tersebut ditarik ke belakang maka sebenarnya nilai tersebut sangat relevan. Penguatan nilai lokal ini justru semakin menguatkan posisi Kampung Mahmud sebagai kampung religi. Dengan begitu maka nilai adat dan tradisi yang diletakkan fungsinya untuk menjalankan syiar agama tentu akan sangat implementatif. Sesepuh Kampung Mahmud tentu tidak hanya berfikir parsial, misalkan pada zaman dahulu saja namun juga sudah memikirkan zaman sekarang.

Pernikahan yang dilakukan antar warga atau keluarga di kampung Mahmud juga merupakan sebuah nilai lokalitas yang menarik. Tidak bisa dipungkiri jika beberapa tata acara dalam acara keagamaan Islam di setiap daerah berbeda-beda. Maka dari itu sesepuh di kampung ini ingin meletakkan pondasi yang kuat agar ajaran yang sudah diwariskan terus lestari.

Sebagai sebuah identitas yang memang kurang disadari oleh generasi muda, tentu lokalitas perlu dipahami secara menyeluruh bahkan jika dikaitkan dengan modernitas. Hilangnya batas-batas dan ciri identitas di kaum urban selayaknya tidak terjadi pada generasi muda di kampung ini. Hal ini bisa terjadi jika para generasi muda mampu mengolah dan menjadikannya sebagai sebuah ciri khusus. Dengan menyelaraskan kehidupan sekarang -tanpa harus menghilangkan lokalitas- masyarakat Kampung Mahmud sesungguhnya akan menjadi sebuah kampung seperti yang diidamkan sesepuh di masa lalu. 


\section{Kesimpulan}

Jika nilai lokalitas ini sebagai salah satu cerminan nilai-nilai yang menjadi pola sosio kultural masyarakat maka akan menjadi sebuah identitas yang kuat sebagai kampung religi. Orientasi tentang nilai ini sebenarnya adalah pandangan hidup yang berjalan selaras di kampung Mahmud, namun perlu penguatan khususnya pada generasi muda. Lokalitas yang muncul di kampung Mahmud tidak hanya berbicara dalam konteks masa lalu, akan tetapi masa kini. Tidak hanya pada hubungan manusia dengan Tuhan, manusia dengan manusia namun juga manusia dengan alam.

Nilai-nilai lokalitas yang diajarkan pada masa lampau setidaknya jika ditarik lagi ke belakang maka semuanya akan menjadi relevan dan sangat kontekstual dengan pandangan hidup yang berjalan di masyarakat kampung Mahmud. Jika kampung ini tidak bisa menghindari modernitas, namun setidaknya nilai lokalitas yang hidup tesebut akan mampu menyelaraskan kehidupan masyarakat bahkan memajukan masyarakat baik dari segi religi, ekonomi maupun sosio kultural.

\section{Catatan Akhir:}

${ }^{1}$ Eyang Mahmud adalah sebutan lain dari Eyang Dalem Abdul Manaf.

\section{KEPUSTAKAAN}

Barker, Chris. 2011. Cultural Studies; Teori dan Praktik. Kreasi Wacana, Yogyakarta

Endraswara, Suwardi. 2006. Metodologi Penelitian Kebudayaan. Gadjah Mada University Pres. Yogyakarta.

Kutha Ratna, Nyoman, 2010. Metodologi Penelitian, Kajian Budaya dan IImu Sosial Humaniora Pada Umumnya. Pustaka Pelajar; Yogyakarta.
Parker, Ian. 2005. Qualitative Psychology: Introducing Radical Research. Open University. Press UK Limited.

Pawito. 2010. Media Massa, Globalisasi, dan Identitas Nasional Surakarta: UNS Press. Pidato Pengukuhan Guru Besar Teori Komunikasi pada Fakultas IImu Sosial dan IImu Politik Universitas Sebelas Maret Surakarta, 7 Januari 2010.

Sobur, Alex. 2014. Komunikasi Naratif; Paradigma, Analisis dan Aplikasi. Remaja Rosda Karya, Bandung.

Spradley, J.P. 2007. Metode Etnografi (Rev-ad). Tiara Wacana, Yogyakarta. Diterjemahkan Misbah Zulfa Elizaberth. Buku asli diterbitkan tahun 1997: The Etnographic interview. California: Wadsworth Publishing Company.

Yasraf Amir Pilliang \& Jejen Jaelani, 2018. Teori Budaya Kontemporer; Penjelajahan Tanda dan Makna. Cantrik Pustaka, Yogyakarta.

\section{Narasumber:}

1. Haji Mohammad Syafei (67), sesepuh Kampung Mahmud dan keturunan ke-9 Eyang Dalem Mahmud. Kampung Mahmud, Mekarrahayu, Kopo Bandung Jawa Barat.

2. Haji Nuron (60), keturunan Eyang Dalem Mahmud ke-10. Kampung Mahmud, Mekarrahayu, Kopo Bandung Jawa Barat.

3. Rustandi (50), ketua RW sampai tahun 2018. Kampung Mahmud, Mekarrahayu, Kopo Bandung Jawa Barat.

4. Ence (56), ketua RW dari tahun 2018 hingga penelitian berlangsung. Kampung Mahmud, Mekarrahayu, Kopo Bandung Jawa Barat. 